\title{
Australia, China and the maritime 'rules-based international order': comparing the South China Sea and Timor Sea maritime disputes
}

\section{Mark Beeson and Andrew Chubb}

\begin{abstract}
Despite systemic internal and external differences, Australia and China have shown striking similarities in their pursuit of disputed maritime resource and jurisdictional claims. This highstakes area of international politics is governed by a codified, globally accepted international legal regime (UNCLOS), making it an important case for examining the relationship between states' foreign policies and the 'rules-based international order' (RBIO). In the South China Sea, Beijing is haunted by the legacy of its strong geopolitically-driven support for an expansive law of the sea regime in the 1970s. Strategic considerations also drove Australia's belated embrace of international legal processes in the Timor Sea in 2016. Before that, successive Australian governments had been as keen to pursue national maritime interests through bilateral negotiations as their Chinese counterparts. Australia's shift was enabled by pro-Timor domestic public opinion and a confluence of geographic and commercial circumstances not present in the South China Sea.
\end{abstract}




\section{Introduction}

Australia and the People's Republic of China (PRC) are systemically dissimilar, internally and externally. One is an authoritarian single-party state, and a great power with expanding global interests; the other is a liberal-democratic 'middle power' with a limited capacity to influence events in its own region. Counter-intuitively, however, in maritime disputes both states have wielded hard-power advantages over smaller neighboring disputant countries, while at different times sacrificing significant material interests to build and strengthen the international maritime legal order. The PRC was once a strong advocate of expanding the reach of codified international maritime law, particularly the UN Convention on the Law of the Sea (UNCLOS). It is only over the past two decades that China's resistance to these international maritime rules has emerged - as manifested in its vehement rejection of the Philippines' arbitration case initiated in 2013 over the South China Sea dispute. For its part, Australia's recent high-profile support for the application of the UNCLOS in maritime disputes is a relatively new development. Until 2016, successive Australian governments were as keen to pursue the narrow 'national interest' at sea through bilateral negotiations, while avoiding rule-based international dispute resolution, as their Chinese counterparts are today.

Comparison of these least similar cases (Gerring and Seawright 1994) and their evolving policies on these high-stakes issues of sovereignty, resources and international order offers payoffs for both international relations scholarship and current policy concerns. It demonstrates, first of all, how high-stakes maritime dispute policies result from much more than 'rational' calculations of material interest under international anarchy. Chinese and Australian policymakers' definitions of national maritime interests, and the policies that have flowed therefrom, result from interactions between 'external' and 'internal' factors that neither level of analysis alone can explain. We find that international legal frameworks, material capabilities, domestic public opinion, and state-business relations have, in combination, had varying effects on state decisions at different times. This, in turn, suggests that to understand when states will and will not support international institutions, it is necessary not only to examine their external systemic position, and their internal constitution, but also interactions with other material and ideational factors such as distinctive histories and sheer geography. In turn, comparing the policies of two very different states towards the 'global constitution for the world's oceans' helps shed light on the ontological status and causal significance of 'rulesbased international order' (RBIO), which has become the rhetorical centrepiece of the foreign 
and security policy discourse of both Australia and its principal ally the United States (Beeson 2019; Strating 2018).

The remainder of the article proceeds in three sections. We begin by briefly outlining the conceptual and empirical terrain that shapes foreign policy decisions in this area. While there are arguments over the nature of the RBIO - as a coherent set of extant institutions or a rhetorical discursive construction - we demonstrate that insofar as international order does exist, the UNCLOS is surely a crucial part of it. The second section details the transformation of China's policies toward this RBIO at sea via its policies in the South China Sea dispute, based on Chinese-language party-state materials including maritime agency yearbooks, internal-circulation reports, policy statements and leadership speeches. The PRC today is haunted by the legacy of its strong geopolitically-driven support for the expansion of the law of the sea regime in the 1970s. But we also show how Beijing's contentious claims in the South China Sea have expanded and hardened not simply as a consequence of its growing power and ambition, but also as a consequence of a major redefinition of its interests at sea that was set in motion by its engagement with, and internalization of, the UNCLOS regime itself.

In the third section, we detail Australia's realpolitik approach in the Timor Sea dispute over four decades, despite significant domestic and international opposition, until its sudden acceptance of an UNCLOS-mandated conciliation process to settle the dispute in 2016. Tracing the continuities and changes in Australian responses to Timor-Leste's attempts to use UNCLOS to bring about the delimitation of a maritime boundary, we show Canberra's belated embrace of the maritime RBIO to be driven by similar geostrategic considerations that motivated Beijing in the 1970s. However, while Australian policymakers now regard strengthening the maritime legal order as an important means of checking China's pursuit of its regional ambitions, it is unlikely they would have found this policy option attractive were it not for pro-Timor public opinion at home, and a fortuitous confluence of geography and commercial imperatives. We conclude by discussing the theoretical implications of the evolving approaches of these two systemically dissimilar states to the international maritime order.

\section{Conceptualising the RBIO(s)}


The character, significance, and even the basic existence of a 'rules-based international order' have been fiercely debated in recent years. While politicians often refer to it as though it were a tangible object, some analysts have argued it is little more than a myth (Allison, 2018). Between these two positions, a range of arguments have been advanced regarding its precise content and origins (Rapp-Hooper, 2018; Staniland, 2018). For our purposes, the RBIO's significance is as a conscious attempt to shape the behaviour of states by binding them to an order of a sort that has been associated with 'American hegemony' and a particular set of institutionalised trade and even security practices (Ikenberry 1998; Narizny 2012). Johnston (2019) points to the existence of a range of distinct international orders, with which individual states may have varying relationships.

Particular governance regimes were famously defined by Krasner (1982, p. 185) as 'principles, norms, rules, and decision-making procedures around which actor expectations converge in a given issue-area'. Subsequently, they have also increasingly been seen as potentially important sources of policy learning, with a widespread observation that states, in general, and rising powers such as China, in particular, could be 'socialised' into appropriate behavior by their very participation in extant regimes, including those created under the auspices of American hegemony (Johnston, 2008; Beeson, 2018).

Our cases suggest, on the one hand, that the degree of emulation and learning on China's part has been more instrumental and limited than the more optimistic assessments may have expected (Chin, 2012). Indeed, in some areas, China is actively attempting to create its own alternative international orders, which reflect its preferences and interests (Beeson and Li, 2016). At the same time, the Trump administration has shown a lack of commitment to the institutional orders its predecessors created (Kagan, 2018). For American allies such as Australia, this compounds existing insecurities about the intentions of China and the long-term commitment of the United States to the stability of the Asia-Pacific region. However, we also find Australia itself has adopted an instrumental and at times hypocritical approach to key aspects of 'the' RBIO. In what follows we focus on the similarities and variations between China and Australia's interactions, across several decades, with one of the most important of these RBIOs: the UNCLOS, which governs state jurisdiction and conduct in maritime spaces. 
The RBIO's recent rise to discursive prominence has not been coincidental. The Australian government in particular has strongly emphasized the existence of a singular international order comprised of the status quo legal and normative principles. As its most recent foreign policy White Paper puts it, 'Australia's security and prosperity would suffer in a world governed by power alone. It is strongly in Australia's interests to prevent the erosion of hard-won international rules and agreed norms of behavior that promote global security' (GoA, 2017, p. 24). Such concerns have become a 'rhetorical centrepiece' for Australian foreign policy over the past 10 years since China's re-emergence as a great power transformed the way Australian and many other policymakers thought about international relations in the Asia-Pacific (Bisley and Schreer, 2018). This recent outspoken support for the RBIO is a function of both China's rise, and Australia's strategic reliance on the United States as the notional bedrock of an institutional order that emerged under the auspices of American power (Beeson, 2015). For its part, the US has adopted the construction in pressuring its junior ally to play a more active and assertive role in combating China's influence. As US Secretary of State Mike Pompeo put it during a 2019 visit to Canberra, 'the rules that the world has used for 100-plus years now, democratic institutions that have done so much good for the people of the US and the people of Australia, will be the world that governs trading systems and security systems for the decades to come' (Norington and Stewart, 2019).

Chinese policymakers and analysts, by contrast, have often characterized the status quo rules of existing institutions as the illegitimate outcome of American 'hegemonism' (Zhou, 2016). However, this has not stopped Beijing's policymakers from taking advantage of the benefits of participating in such international institutions when it suited them. Indeed, China's economic rise has been facilitated by its integration into a global capitalist economic system in general and its accession to the World Trade Organization (WTO) in particular (Lake, 2018). Despite the misgivings expressed by some in China about the onerous conditions attached to its accession to the WTO in 2001 (Lardy, 2001), there is little doubt that this experience provided Chinese policymakers with an important entrée into the global trading order constituted by American-inspired liberal principles and norms.

China's 'rise' was undoubtedly accelerated by its economic opening and the dramatic increase in foreign investment and economic engagement that accompanied it. But there is an ongoing and inconclusive debate about the subsequent degree of 'socialization' that has occurred on the 
part of China's policy elites, diplomats and population more generally (Johnston 2008; Stenifeld 2010). On one hand, it is clear that 'China' is not the same country that it was when it acceded to the WTO, let alone forty years ago when its era of 'reform and opening' era began. China's rapidly expanding middle class, its prominent economic entities, and its increasingly capable policy elites are among the most visible manifestations of this reality. On the other hand, however, the continuing centrality of the Communist Party and the increasing centralization of power under Xi Jinping confirm that PRC remains a very different kind of state to the United States, or to Australia (Lampton, 2015; Johnson and Kennedy, 2015). Indeed, the direction of PRC's recent political development raises the possibility that China's interactions with some aspects of the international order may actually have had the opposite effect to those predicted by liberal institutionalism. The case of China and the UNCLOS detailed below offers another suggestive example of this.

One of the ironies of the highly institutionalised international order inaugurated by the US and its allies in the aftermath of the Second World War is that it has created formidable economic rivals for the US as first Japan and latterly China challenged America's economic dominance (Beeson, 2014). In China's case, its ongoing systemic difference and unfulfilled regional ambitions has shaken Washington's own commitment to the institutional order, and presented a major strategic challenge for Canberra. These concerns have also been reinforced by the unpredictable, 'transactional' approach to foreign policy-making displayed by the Trump administration, which considers the PRC to have taken advantage of the very system of economic openness the US initially strove to create and defend (Stokes 2018). Elements of the administration's 'America First' approach pose a potentially existential threat to the operation of core international institutions (Wolf, 2018). In this context, Australia's RBIO rhetoric is about more than trying to shape China's behaviour; it is also aimed at encouraging America's current policymakers to abide by the system it created (Smyth, 2017).

In a further paradoxical recent development, China has been attempting to position itself as a champion of globalization and the extant international order in response to America's apparent repudiation of key institutions that once underpinned its leadership (Xi, 2017; Xi, 2018). In fact, in the context of a US administration with little tangible commitment to free trade or international political and legal institutions, the PRC today has begun to explicitly claim the mantle of protector of the international 'rules-based international order' (CCTV, 2018). The comparative analysis that follows will highlight the complex interplay between such discursive 
constructions, extant institutions of international order, domestic politics and geography in the calculation of 'national interests'. Indeed, we find the continuing influence of sheer geography is an important and often under-appreciated element of this story, and one that has profoundly influenced differing conceptions of national interests in China, Australia and the US, for that matter (Kaplan 2012; cf Agnew 2018). First, however, we will offer a closer look at the evolution of the maritime aspect of RBIO and its underlying rationale.

\section{The RBIO at sea}

Given Australia's and China's different histories and internal constitutions it is perhaps noteworthy that — unlike the US — they are both parties to the UNCLOS in the first place. While both countries' attitudes toward the UNCLOS has been inconsistent and self-serving, it is precisely the sort of institution we would expect a liberal-democratic ally of the US to support in principle. By contrast, the PRC's Marxist-Leninist-Maoist party-state was openly hostile to the concept of international law when negotiations over the UNCLOS began in 1973, and it had little history of any participation in international legal regimes. What the PRC did have, however, was a strong sense of its vulnerability to American and Soviet 'maritime hegemonism'. The UNCLOS eventually concluded at Montego Bay, Jamaica in 1982 offered weaker states the prospect of constraining the behaviour of great powers in the way liberal analysts of American foreign policy suggested it might (Ikenberry, 1998). It is worth spelling out its key features.

First, it is a fully codified, legally binding international treaty with global legitimacy. Painstakingly negotiated over nine years (1973-1982), the main text of the Convention contains 320 articles, specifying in detail the rights and responsibilities of states at sea. Its scope is vast, regulating activities ranging from resource exploitation to scientific research and environmental protection, and covering areas from internal waters and territorial seas to Exclusive Economic Zones (EEZs), continental shelves and even the high seas. In essence, it defines the rules for who can do what in all different parts of the ocean. Originally signed by 107 governments in 1982, it has now been signed and ratified into domestic law by 157 of the world's states. As such, its proponents' claim to have created the 'global constitution for the world's oceans' is not an exaggeration. The fact that the United States has been the only major 
nation not to have ratified the Convention only underscores its position as a part of a global normative order that is more than simply a function of power politics.

The second key feature of the 1982 UNCLOS is its radical expansion in the scope of state authority at sea. A key reason why so many states voluntarily signed up to significant constraints on their freedom of action internationally was that it offered them the chance to lay claim to the world's ocean spaces on a scale never before seen. The first UN Conference on the Law of the Sea, in 1958, codified an existing norm of $12 \mathrm{~nm}$ territorial seas, and affirmed state jurisdiction over seabed resources on their continental shelf. But the 1982 agreement created the concept of EEZs, assigning governments sovereign authority over the resources of both the water column and the seabed out to $200 \mathrm{~nm}(370 \mathrm{~km})$, as well as on the continental shelf out to $350 \mathrm{~nm}(650 \mathrm{~km})$. This had the effect of subjecting nearly 50 per cent of the world's maritime space to claims of state jurisdiction. In this sense, the UNCLOS concluded in 1982 constituted an unprecedented carve-up of maritime space - the 'territorialization' of the world's oceans (Oxman 2006).

The third key feature of the UNCLOS is its provisions for supra-national adjudication on the application of its rules. The document was created explicitly with the goal of establishing 'a legal order at sea' in order to serve not only political, but also social and environmental goals (UN 1982, p. 25). The price the signatories paid — or were supposed to pay — in exchange for authority over vast new expanses of the world's oceans was to allow independent adjudication of competing claims, and protect the sustainability of the marine environment under their jurisdiction. The UNCLOS therefore established new international bodies including a multilateral Commission on the Limits of the Continental Shelf (Annex II), the International Tribunal on the Law of the Sea (Annex VI), as well as providing for compulsory conciliation and arbitration processes (Annexes V and VII respectively). As such, the UNCLOS was created not only as a set of rules, but also a set of supra-national mechanisms for applying those rules.

These three features of the UNCLOS - its codified and globally legitimate rules, the expansion of state jurisdiction at sea that it permitted, and its provisions for supra-national application of its rules - make it a clear site of overlap between the RBIO as a discursive construction and the existing international order comprising shared institutions and norms. Put simply, if the RBIO is more than a myth, then the UNCLOS is surely a key part of it. The tangibility and global legitimacy of the UNCLOS, combined with the fact that it regulates state 
competition in high-stakes domains such as boundary demarcation, energy and fishery resources, gives states strong ideational incentives for both compliance and defection. This makes it a useful lens through which to explore the relationship of foreign policies to the RBIO, for it implies that the factors that would produce policy change in this area would be relatively strong. To understand when or if states will follow the international order at sea, it will make sense to examine the policies of two contrasting countries, both with significant disputed maritime claims with weaker neighbors, across time. Below, therefore, we examine the evolution of China and Australia's policies in their maritime disputes, and their relationship to this RBIO at sea.

\section{China's struggle for, and against, UNCLOS}

Since 1973, China's relationship with the UNCLOS has shifted from a strong supporter, into a period of ambivalence marked by the recognition of both challenges and opportunities, to strong resistance to the application of formally codified global maritime rules. But far from considering international law a meaningless non-constraint, the PRC's policymakers have been acutely aware of the instrumental political uses that it can be put to. In fact, the party-state today is haunted by its past exploitation of the UNCLOS for political purposes.

From the 1970s, China's ideologues saw the UNCLOS as a powerful tool for resisting superpowers' 'maritime hegemonism,' During the decade-long negotiation process leading up to the treaty's conclusion (1973-1982) the PRC's representatives advocated strongly for a 200nm EEZ against other, less expansive proposals, arguing this was favourable to third-world countries' interests against great powers (Shan 2012; interview, Beijing, April 2016). At that time of intense existential security threats, especially from the Soviet Union, any initiative that could help build opposition to the activities of extra-regional militaries in East Asia stood to increase Beijing's security (Chen 1994; Wang 2016). Specifically, it provided a new line of argument against military activities over a vastly wider area, extending out to 200 nautical miles from the coast. China supported this expansive scope for the new EEZ regime over more modest proposals, even though this greatly strengthened its neighbours' claims to potentially vast reserves of oil and gas in its maritime periphery that had been identified in preliminary surveys in the late 1960 s. 
With the signing of the UNCLOS in 1982, Beijing gained the ability to mount a legal argument against the activities of powerful navies across a much broader area of its maritime periphery — and today, at least 16 other states agree with China's argument (Pedrozo, 2010, p. 35n49). But it greatly complicated the PRC's claims to resources in the same areas. In the East China Sea, the creation of the 200nm EEZ generated a Japanese claim over approximately one-third of China's continental shelf (Smith, 2015, Chapter 4). And in the South China Sea, it legitimized coastal-based claims of Malaysia, Vietnam, the Philippines, and Brunei over vast maritime spaces to which the PRC was also attempting to advance claims. As Jie Chen has observed, from the perspective of material interests, 'given that the Chinese-claimed area in the South China Sea extends to the doorstep of every coastal state in the area, China should have been the last country to support such a struggle [for a 200nm EEZ]' (Chen, 1994, p. 154). This is illustrated in Figure 1, which shows the effect of the UNCLOS EEZ provision on the Southeast Asian states' coastal-based claims to resources and jurisdiction in the area. China's policy in the South China Sea has been greatly complicated by this legacy ever since.

\section{$<$ FIGURE $1>$}

New legal regime, new interests

Just as the UNCLOS expanded the Southeast Asian countries' coastal-based claims, it also triggered a redefinition of China's interests in its maritime periphery. China's disputed claims in the South China Sea have been depicted since its founding by the 'dash line' map (Figure 2), which the PRC inherited from the Republic of China (ROC), its defeated rival in the civil war. When the ROC first published the map in 1948, the map depicted a claim to the islands (land territories) within. This was clear from the official title given to the map: Location Map of Islands in the South China Sea (南海诸岛位置图). Indeed, there is no sign of the line being treated as a claim to maritime space or resources before 1973. But following the initiation of the UNCLOS negotiations, which introduced the prospect of claims over vast maritime areas via the EEZ concept, this began to change. Starting in 1973, Beijing sent research ships on 11 journeys around the central part of the South China Sea, between the Spratlys and the Paracels, systematically setting up a network of observation stations (SOA 1986, p. 403). Depicted in Figure 3, this to our knowledge constitutes the first evidence of a PRC interest in administering maritime spaces in the South China Sea, as distinct from disputed island territories. 


\section{$<$ FIGURES $2 \& 3>$}

The successful conclusion of the UNCLOS negotiations in 1982 further energized the PRC's new interest in exploiting resources across wide expanses of maritime space, particularly in the South China Sea, where it had long-standing claims to disputed islands. The following year, the China launched an unprecedented series of maritime resource surveys around the nine-dash line (Figure 4) that, as noted above, had originally depicted a much simpler territorial claim to the islands enclosed within. Implemented by the Chinese Academy of Sciences between 1983 and 1987, the scope of these surveys was broad, not only probing for hydrocarbons and assessing fisheries, but also testing for the presence of a range of other minerals and resources such as manganese and copper (CAS, 1989). Following the Seventh Five-Year Plan (19861990), these 'comprehensive surveys' were stepped up further. In 1987 the CAS survey was expanded to include a second survey ship, and stayed in the area almost 50 percent longer than earlier voyages (Zhang 1996, pp. 114-115). Crucially, the routes depicted in Figure 4 indicate that PRC policymakers now understood the nine-dash line to be the extent of the maritime spaces in which these new interests lay. The emergence of the UNCLOS regime had precipitated a shift in the PRC's understanding of its interests in the South China Sea, away from disputed islands, and towards maritime space. Ironically, this reading of the nine-dash line map was fundamentally at odds with the new international legal regime that had triggered its adoption in practice.

\section{$<$ FIGURE 4>}

As the international legal regime matured, China's new claims over vast maritime spaces in the South China Sea progressively hardened. In direct response to the UNCLOS coming into effect in 1994, Beijing enacted a series of laws establishing the PRC's first specific claims to jurisdiction at sea beyond the narrow $12 \mathrm{~nm}$ territorial sea it had claimed since 1958. A programmatic government document released to mark the PRC's ratification of the convention in 1996 stated that 'the UNCLOS EEZ and Continental Shelf systems' had expanded the area of China's maritime jurisdiction nearly tenfold to 'approximately 3 million sq km' (SOA, 1996, Preamble). At this point the PRC maintained its official view that the UNCLOS was 'beneficial to breaking maritime hegemonism' - a glowing accolade within a Marxist-Leninist partystate system (SOA, 1996, ch.10). 
However, as Beijing set about implementing the UNCLOS's provisions, it became increasingly clear that the RBIO at sea would not necessarily always work in its favour. In 1998, China enacted its EEZ and Continental Shelf Law, laying down the first specific domestic legaladministrative basis for exercising jurisdiction over the energy and fisheries resources of the new areas created by the international legal regime. But Article 14 of the EEZ and Continental Shelf Law also reserved a claim to unspecified 'historical rights and interests' (历史性权益) which by implication went beyond those allowed for in the UNCLOS. A new and highly consequential aspect of China's relationship with the RBIO at sea was beginning to crystallize: in addition to advancing its expansive new rights within the new global legal framework, the PRC now considered itself to have a simultaneous struggle for its interests against the UNCLOS.

In January 1999, the PRC's State Council established a national maritime law enforcement force with responsibility for advancing the claims described in its new maritime laws. According to the SOA's official newspaper, CMS was designed as a 'special police force' for implementing UNCLOS and protecting China's 'rights and interests' (Xu, 2000). Significantly, the latter term (权益), around which China's maritime administrative system is built, renders rights and interests indistinguishable. The establishment of CMS was followed in 2000 by major new capacity-building programs to equip the new force - and the existing Fisheries Administration - with a fleet of ships capable of the kind of long-range, high-endurance patrolling necessary to exercise control over the millions of square kilometres of what was now referred to China's 'blue territory' (SOA, 2000, pp. 10-11). The addition of this 'great white fleet' has been integral to China's assertive push through the South China Sea from 2006 onwards (Martinson, 2018). These developments, as we have seen, had begun with a redefinition of China's interests at sea that was UNCLOS-inspired, yet not UNCLOScompliant.

\section{Struggling against the RBIO at sea}

In 2001, on the fifth anniversary of China's ratification of the Convention, SOA Deputy Director Sun Zhihui delivered a programmatic speech in which he observed that since UNCLOS came into effect the 'international struggle over maritime rights,' had intensified due 
to countries around the world enacting legislation, drawing up maritime strategies, and strengthening their maritime rights-and-interests defense and management programs (SOA, 2002, p. 26). By 2003, internal advisory reports were warning decisionmakers in Beijing that the PRC's rivals in the South China Sea were 'using UNCLOS' as a basis for enforcement actions to curtail Chinese activities in disputed areas, particularly fishing in the Spratlys. By the tenth anniversary of the PRC's ratification of the Convention in 2006, the positive assessment of its 'anti-hegemonic' significance was notably absent from party and government statements. A joint forum hosted by the SOA and the Foreign Ministry to commemorate the occasion observed that the 'challenges and opportunities' of the new legal regime were leading all countries to 'continuously strengthen on-water law enforcement forces and elevate administrative control (管控) capabilities in claimed waters' (China Ocean News, 2006).

The next watershed in the PRC's evolving relationship with the UNCLOS followed in August 2006, when the party-state officially opted out of the Convention's compulsory dispute resolution procedures for overlapping maritime boundaries (as discussed below, Australia had done so in 2002). This coincided with the operationalization of the new on-water law enforcement systems initiated in the late 1990s. According to Chinese government researchers, China's immediate concern in 2006 was avoiding dispute resolution proceedings in the East China Sea maritime boundary dispute with Japan (Interview in Beijing, April 2016). But the rejection of compulsory dispute resolution also closely preceded a rapid intensification of the PRC's confrontational behavior in the South China Sea, particularly in areas around the edges of the nine-dash line, where its claim under the UNCLOS regime was weakest (Chubb 2017, Chapter 4). Significantly, the first-ever official use of the 'nine-dash line' map in an Chinese diplomatic document followed in 2009 - in a submission to a UNCLOS-mandated body for assessing Continental Shelf claims. This doubling-down on the nine-dash line set the stage for a prolonged struggle against the maritime RBIO.

The PRC's clash with the system of formal maritime rules it had once sponsored came to a head in January 2013, when the Philippines initiated compulsory arbitration proceedings under Article 287 and Annex VII of the UNCLOS, accusing Beijing of a wide array of violations of the UNCLOS by the PRC. According to PRC government-affiliated researchers, Beijing's belief in the preclusive effect of the 2006 declaration opting out of maritime boundary dispute mechanisms meant the case took China's maritime policy officials and scholars by surprise 
(Interviews in Haikou and Beijing, April 2016). Consistent with this account, the Philippines' move was followed by four weeks' silence, before the MFA finally responded: China would neither accept or participate in the proceedings. Beijing claimed the case was an 'abuse' of UNCLOS procedures that attempted to use mischievous legal sophistry to smuggle what were 'essentially' territorial sovereignty disputes into the scope of the Convention (MFA, 2014). Empowered under UNCLOS Article 288 to decide on the admissibility of cases, the arbitral panel was unpersuaded by Beijing's response, so the case proceeded (PCA, 2015).

In July 2016 after three-and-a-half years of hearings, deliberations and considerations of thousands of pages of evidence, the arbitral tribunal handed down a 501-page decision that found Beijing to have violated the UNCLOS on at least 14 of the 15 counts alleged by Manila (PCA, 2016). In the lead-up to the announcement of the decision, Beijing launched a major domestic and international propaganda campaign aimed at assuring Chinese citizens of the legitimacy of the country's claims, and winning international expressions of support for its rejection of the proceedings. But the maritime jurists' meticulous application of the UNCLOS's rules to China's behavior had made plain the 180-degree reversal of the PRC's relationship with the international order at sea - from third-world solidarity against the superpowers, to joining the United States in rejecting the binding power of international law to curb its maritime behavior.

China's journey demonstrates, first of all, the existence and importance of RBIOs as a resource for international statecraft. Even as China has moved towards rejection of international law as a constraint on its policies in maritime disputes, it has clearly understood it as a vital tool for advancing its interests at sea. In the words of two Chinese military researchers, in international disputes over maritime rights 'whoever grasps the use of international law gains the initiative' (Xiao and Li 2013, p. 101). But, contrary to realist interpretations of institutions as reflecting the interests of the most powerful states, in this case the RBIO has been at least as much a tool of the weak, and of middle powers (as China in the 1970s might be described) as it is a function of underlying power realities. Indeed, the PRC's trajectory has been the opposite of such expectations: when it was weak in the 1970s, the UNCLOS offered China a useful tool to check the superpowers' naval activities, but as its material power has grown, it has found the RBIO at sea increasingly troublesome. 
Second, and most consequentially, the process of negotiating and implementing the UNCLOS redefined China's view of its interests in its maritime periphery - from sovereignty over islands and curbing superpower surveillance, towards control over vast maritime spaces and resources. As we have seen, the new rights provided for by the UNCLOS catalyzed the PRC's interest in the natural resources of disputed areas in the 1970s and 1980s, in the 1990s the convention's enactment prompted new domestic legal implements authorizing the advancement of these new maritime interests, and in the 2000s new law enforcement fleets were constructed to enforce them. These developments, part of the maritime 'territorialization' process intrinsic to the building of the UNCLOS, catalyzed China's shift to an assertive policy of advancing control over the South China Sea's disputed maritime spaces since the late 2000s.

\section{Australia in the Timor Sea: a middle power changes its mind}

In April 2016 Timor-Leste, the small half-island nation of 1.1 million people, initiated compulsory conciliation proceedings under Annex V of the UNCLOS, aimed at demarcating its disputed maritime border with Australia. This move followed more than fifteen years of disputes, three international legal cases, and a protracted campaign to mobilize domestic and international public opinion over the issue (Strating, 2018; Laksmana 2017). The following year, the two countries announced that the UNCLOS-mandated conciliation had produced an agreement settling the disputed maritime border. This was formalized in a March 2018 treaty that Australia described as 'an example of the rules-based order in action' (GoA, 2018).

Australia had for decades resisted the application of international legal processes to the dispute, insisting on bilateral negotiations with its smaller neighbour, and obstructing legal proceedings over the issue. As Strating has noted (2017, pp. 274-277), realpolitik had been a consistent feature of Australia's policy towards the Timor Sea for more than four decades. Like the PRC in the 1970s, Australia embraced maritime institutionalism for strategic reasons. But beyond this basic impetus, other factors were crucial in Australia's move towards good international maritime citizenship. The policy shift was facilitated by liberal political institutions that enabled persistent pro-Timorese domestic pressure, as well as fortuitous geographical contingencies — both conditions absent in the case of China and the South China Sea. 
Across the Timor Sea: the bilateral context

While technically bilateral in nature, the Australia-Timor maritime dispute has a history almost as complex as the South China Sea disputes. Australia's interests in the area's oil and gas date to the early 1960s, when it began issuing exploration permits (Dixon, 2017, p. 1). The roots of dispute lie in the 1972 seabed boundary agreement between Australia and Indonesia, under which Canberra secured jurisdiction over oil and gas resources extending most of the way to the Timor Trough, a deep undersea ravine only around 40 nautical miles from the island of Timor (Figure 5). This agreement reflected the 'natural prolongation' of the continental shelf as the primary basis for maritime delimitation, as had been endorsed by the International Court of Justice in the 1969 North Sea case (Schofield, 2007, p. 191). However, the AustraliaIndonesia bilateral treaty did not apply to the area between Australia and the Portuguese halfisland colony of Timor-Leste. This left a $120 \mathrm{~nm}$ undelineated section that became known as the 'Timor Gap' — which happened to contain some of the most promising hydrocarbon prospects. Timor-Leste became independent from Portugal in November 1975; in addition to the allure of oil and gas, Canberra was concerned about leftist leanings among the new nation's leaders, and thus favoured 'integration' of the Roman Catholic half-island into General Suharto's Indonesia. One month later, the Indonesian military invaded, commencing an occupation that resulted in a death toll estimated at more than 100,000 people (CAVR 2013, p. 494).

\section{$<$ FIGURE 5>}

For nearly 24 years, Australia stood virtually alone in recognizing Indonesia's claim to TimorLeste. In accordance with Australia's long-term strategy of securing control of the oil and gas of the area, by 1979 Canberra and Jakarta had begun negotiations to exploit the promised oil and gas bounties of the Timor Gap (Cleary, 2007). But by this time, the norms of maritime boundary delimitation had changed appreciably from those prevailing in the two countries' earlier 1972 agreement. The creation of the EEZ in 1982 further shifted the basis of delimitation away from undersea geography — the continental shelf — in favour of an equitably adjusted median line (Schofield, 2007, pp. 198-199; Rothwell, 2018, par.3). On this basis, Jakarta laid claim to the resources of the Timor Gap halfway to the Australian coast, while Australia clung 
to its 'natural prolongation' argument. In 1989 the two sides agreed on the Timor Gap Treaty, infamously clinched by the two Foreign Ministers over champagne in a jet flying over the area, dividing up the proceeds from the exploitation of oil and gas in a joint petroleum development zone on the Timor side of the median line (Figure 5).

After the fall of the Suharto regime in 1998, the new government in Jakarta permitted TimorLeste to hold a referendum on whether or not to remain part of Indonesia. Seventy-eight percent voted in favour of independence. But as the occupying Indonesian military withdrew, proIndonesian militia unleashed a wave of violence, and most of the new nation's infrastructure was destroyed. Australia led a UN-mandated intervention to restore order, and the UN set up a Transitional Authority for East Timor (UNTAET) to manage Timor-Leste's transition to democratic self-government (Cotton, 2004). The UNTAET and Australia agreed to continue operations in the joint petroleum development area established by Indonesia and Australia in 1989, without prejudice to the nascent Timorese state's position on its maritime boundaries. The ostensible goal was to ensure the new state had a source of income. But Australia's subsequent actions would make clear that its realpolitik approach to the Timor Sea's oil and gas had not changed (McGrath 2017).

\section{Bullying and obstruction with Australian characteristics}

Australia's actions in the Timor Gap after 1999 are at odds with its claims to be a staunch supporter of the international maritime legal order. In November 1999, with its neighbour under UN transitional authority and reeling from the chaotic and violent end to Indonesia's occupation, Australia commenced production at the Laminaria-Corallina oil and gas fields (Figure 5). Although these resources lay outside the joint development zone established in 1989, the Timorese political leaders understandably did not consider themselves bound by the unfavourable agreements that had been negotiated by Indonesia - agreements that in part reflected a quid pro quo for Australian recognition of its bloody occupation (Rothwell, 2018, par. 4). Importantly, given the decisive shift towards equidistance lines in international maritime boundary demarcation practice, Timor had a plausible claim to these resources (Simpson, 2014; Schofield, 2007, pp. 199-200). The area also lay inside a temporary Timorese maritime boundary established for the purposes of the international military intervention (King, 2018, p. 41). Despite Dili's repeated protests against this unilateral development, the fields 
were exhausted with Timor-Leste receiving none of the estimated $\$ 2$ billion in revenues (Clarke, 2018; Schofield, 2007, p. 200 note 42; King, 2018, pp. 53-59).

In May 2002, two months before the end of the UNTAET's mandate and the formal establishment of the Democratic Republic of Timor-Leste as a sovereign state, Australia withdrew from compulsory international maritime border dispute resolution under UNCLOS and the International Court of Justice. This precluded demarcation of the Australia-Timor maritime boundary by a supranational legal authority, and thereby 'forced Timor-Leste to negotiate bilaterally in the context of significant power asymmetry' (Strating, 2017, p. 260; see also Anton, 2014). In a comment strikingly resonant with Beijing's position on the South China Sea, Foreign Minister Alexander Downer stated: 'Australia's strong view is that any maritime boundary dispute is best settled by negotiation rather than litigation'. Prime Minister John Howard described the move as 'legitimate protection of a national interest' (King, 2018, p. 51). Desperate for fiscal revenues, and unable to seek international adjudication under the UNCLOS, Timor-Leste signed a successor to the 1989 Australia-Indonesia agreement on the day of its independence. This Timor Sea Treaty (TST) allocated Dili 90 per cent of the upstream revenues from the joint development zone (Indonesia had settled for 50-50 split), but the estimated 3.4 trillion cubic feet (tcf) of gas from its biggest development, Bayu-Undan, would be piped to Darwin for processing, delivering Australia significant downstream revenues and flow-on economic benefits.

The 2002 treaty also left unresolved the status of the Greater Sunrise field, a much larger deposit of an estimated 10 tcf straddling the eastern edge of the JPDA (see Figure 5). A 2003 agreement placed 79.9 percent under Australian jurisdiction, and only 20.1 percent of the field in the JPDA. According to some estimates the revenue from the Greater Sunrise gas deposits might run to US\$40 billion, with running costs and initial investment accounting for nearly US\$30 billion, leaving around US\$11-12 billion for Timor and Australia and the commercial developers to negotiate over (Evans, 2018). While Timor-Leste pressed Australia to delineate a maritime boundary, Australia resisted on the grounds that it doing so might entail renegotiating other settled maritime boundaries (Interview, Chengdu, November 2018). Legal experts have argued this was unlikely (Schofield 2007, p. 201). In any case, the result was that the commercial consortium developing Sunrise shelved its operations in January 2005, pending the outcome of further negotiations between Canberra and Dili. 
The negotiations over Greater Sunrise produced reports of 'belligerent and aggressive' conduct from the Australian side. A leaked transcript of one exchange recorded Foreign Minister Downer telling the Timorese Prime Minister Mari Alkatiri:

"We don't have to exploit the resources. They can stay there for 20, 40, 50 years. We are very tough. We will not care if you give information to the media. Let me give you a tutorial in politics — not a chance." (Steele, 2003)

Australia's chief negotiator reportedly told the Timorese side that Canberra was prepared to hold out for '99 years' if necessary (King, 2018, p. 63) - a serious threat given Timor-Leste's looming dependence on Greater Sunrise revenues for its basic governmental functions. In 2006, the two sides agreed on the Treaty on Certain Maritime Arrangements in the Timor Sea (CMATS), under which Timor agreed to drop its demand for demarcation for 50 years or the life of the project, in exchange for half of the upstream royalties. But Timorese officials suspected their negotiating positions over CMATS may have been compromised by espionage (Cleary 2007). Those suspicions turned out to be warranted.

Australia's belated embrace of the maritime rules

In April 2013, Timor-Leste launched arbitral proceedings in The Hague aimed at annulling the CMATS treaty on the grounds that Australia had eavesdropped on its internal deliberations during the negotiation period. The key witness was a former Australian intelligence official known as Witness $\mathrm{K}$, who had come forward with the explosive claim that he had overseen the installation of listening devices in the Palace of Government in Dili under the cover of an aid project (Shanahan 2013). The whistleblower was motivated by what he regarded as the misuse of his agency for commercial purposes during a time of heightened threats of terrorism. Timorese Prime Minister Rui Maria de Araújo described the eavesdropping as 'at least morally' criminal (Cannane et al., 2015). Certainly, it stood to compromise Dili's already weak negotiating position, and Timor thus argued the CMATS had been negotiated with an absence of the 'good faith' required under the Treaty of Vienna. Australian authorities responded by raiding the offices of the whistleblower and his lawyer in December 2013, seizing documents relevant to the case. Two years later, Foreign Minister Julie Bishop blocked the return of the witness's passport, preventing him from traveling to The Hague to testify (Cannane, 2016). 
By early 2016, then, the approaches of Australia and China to their respective maritime disputes had converged around (1) steadfast insistence on bilateral negotiations in a context of power asymmetry, and (2) the avoidance of - and where necessary non-cooperation with international legal processes. This conspicuous similarity only ended with Australia's belated embrace of Timor's UNCLOS conciliation proceedings in August 2016. What, then, explains the change in Australia's position?

There were strong strategic reasons for Australia's shift to embrace maritime institutionalism in 2016 - just as there had been for the PRC in the 1970s. If Australia's embrace of UNCLOS process in the Timor Sea stood to strengthen the maritime legal order, this could help serve as a check on China's advances in the region. More specifically, it enabled Australia to strongly support the Philippines $v$. China arbitration process, and eased pressure from the US Obama administration to resolve the dispute in order to do so more effectively (Murdoch 2018). As McGrath (2017, pp. 190-191) points out, until the contradiction with Timor-Leste was resolved, Australia would be 'unable to lend credible support to the United States and its ASEAN neighbors in their dispute with China in the South China Sea'.

This sequence of events through 2016, together with official statements from Australian policymakers, provide compelling evidence of this link between the two UNCLOS cases. When Timor initiated its conciliation proceedings in April 2016, Australia initially opposed the process, declaring that 'Timor Leste's decision to initiate compulsory conciliation contravenes prior agreements between our countries not to pursue proceedings relating to maritime boundaries' (Allard, 2016). When the Philippines v. China arbitration decision was handed down in July, detailing China's breaches of the UNCLOS, Australia was adamant that the ruling was legally binding. Just one month later, in August 2016, Australia announced it would abide by the Timor conciliation commission's decision on whether to proceed. Foreign Minister Julie Bishop explicitly linked Australia's stance on the two cases: 'In both situations we emphasise the importance of the rule of law and the willingness to resolve disputes peacefully’ (Hodge, 2016).

Public opinion, geography, and multinationals 
The realpolitik of successive Australian governments was not only resented by Timorese, who had fought on Australia's side against Japan in World War II, it was also widely opposed in Australia (McGrath, 2017, p. 140). Opposition within the Australian community came from numerous sources. Timorese exiles pursued international support for their homeland's autonomy. Social justice-oriented civil society groups, as well as religious interests, campaigned strongly and persistently on the Roman Catholic country's behalf. Many Australian military veterans, particularly those associated with the $2 / 2$ nd commando squadron that worked closely with the Timorese population in a guerilla struggle against Japan during World War II, were incensed at the betrayal of their wartime allies (Ayris, 2006). The murder by Indonesian forces of a group of Australian journalists covering Indonesia's invasion in 1975 further helped establish Timor-Leste a cause célèbre for the Australian mass media and their audiences. The Australian parliamentary opposition also broke the bipartisan consensus on several occasions, most recently from 2015 onwards when the Australian Labor Party introduced maritime boundary settlement into its national platform (ALP, 2015, p. 197).

Australia has thus had to contend with domestic criticism of its tough approach in a way that China has not - and Australian public opinion has permitted Canberra to move to compliance in a way Chinese public opinion, conditioned by years of nationalist propaganda, may not. To be sure, the powerful strain of pro-Timorese sentiment within Australian public opinion was never sufficient to alter Canberra's policy while bipartisan consensus existed over Timor Sea policy. But the consistent pressure ensured that Australian leaders' uncompromising pursuit of 'the national interest' was by no means costless. For authoritarian China, the domestic political cost-benefit calculus is reversed: the ruling party faces negligible domestic opposition to its belligerence over the South China Sea issue, while an approach more acceptant of international legal authority could be prohibitively costly for leaders in Beijing. There is little evidence to suggest public opinion has been driving the PRC's assertive conduct (Chubb, 2019), but given the nationalist sentiments Beijing has cultivated over the issue, agreements like that between Australia and Timor, involving the revising of lines on official maps, may be politically unviable without significant work to reshape public opinion. At present, in the context of a positively shifting balance of power, Beijing's policymakers probably have little reason to desire such compromise (Zhang, 2016). But under different circumstances, this inflexibility could become a meaningful constraint from UNCLOS-compliant maritime boundary demarcation. If so, then public opinion could ironically end up exerting a more direct influence on authoritarian China's conduct than liberal-democratic Australia's. 
The interaction of geography and commercial interests is a further key factor that has facilitated Australia's embrace of the RBIO at sea. In its 2018 boundary agreement Canberra conceded the median line position it had resisted for so long (Figure 6). But while Australia has abandoned its 'natural prolongation' argument claiming jurisdiction all the way out to the Timor Trough, the trench is a major factor influencing the decisions of the notionally independent multinational corporations that will ultimately develop (and profit from) the oil and gas deposits of Greater Sunrise. Specifically, constructing a pipeline across the trench would present major engineering challenges, leaving Australia a more attractive location for the downstream processing of Sunrise gas, despite the field's close proximity to the southern coast of Timor-Leste (McDonald-Smith, 2018). This combination of geographical contingency and commercial imperatives has effectively allowed Australia to outsource its position on this key negotiating point to multilnational corporations.

\section{$<$ FIGURE 6>}

Development-minded Timorese leaders have strongly pushed for a pipeline to the south coast of Timor, and onshore processing of the gas there. Under the 2018 Treaty, if the gas is piped to Darwin then the upstream revenues will be split 80-20 in Timor's favour; if the pipeline goes to Timor the split will be 70-30. Failure to reach an agreement on this final sticking point is a much bigger problem for Timor than it is for Australia. As Schofield and Strating point out: 'While Australia was motivated to reach a settlement with Timor-Leste by the desire to remove a persistent irritant in bilateral relations (as well as to remove a source of censure for Australia on the international stage), the commercial partners are not subject to the same pressures.' (Schofield and Strating 2018). Australia has thus been able to allow the private sector to maintain the pressure on the Timor-Leste government to accept the piping of gas to Darwin, while its compliance with international legal processes reinforces a wider set of geopolitical and foreign policy goals.

By strengthening and accentuating the RBIO, Australia hopes to constrain China by increasing the costs of the ongoing extension of its material power, particularly at sea. It is important in such circumstances that Australia appears to be subscribing to the norms and principles of the RBIO it now advocates so vociferously. Fortunately for Australia, two combinations of interacting contingent and structural factors - history and liberal institutions on one hand, and 
commercial interests and sheer geographical reality on the other - have allowed it to do so at a discount.

\section{Conclusion}

What can the similarities, differences and changes in the foreign policy behaviour of the PRC and Australia in relation to the UNCLOS tell us about foreign policy decisions and international politics? First of all, the fully codified, globally legitimate legal regime governing high-stakes maritime resource and jurisdictional rights offers a revealing lens through which to understand states' relationships to 'the' RBIO. This comparative analysis has demonstrated striking, counter-intuitive and hitherto under-analysed similarities between the policies of Australia, a liberal-democratic middle power, and the $\mathrm{PRC}$, an authoritarian great power, in resisting or obstructing the RBIO when dealing with a maritime dispute with a much smaller opponent. Asymmetries of power and influence continue to matter in the conduct of international relations, even for those states - such as Australia - that portray themselves as principled middle powers and supporters of the RBIO. In reality, Australia has often been just as willing to resist the rules as China when its leaders have judged it in their interest to do so.

At a time when the durability and authority of the RBIO are uncertain (Haas 2018), this comparative case study has potentially important implications for contemporary policyoriented and theoretical debates about governance and international order. First — and least surprisingly, perhaps - states are prone to using the maritime RBIO instrumentally in pursuit of the 'national interest', even when the latter is discursively constructed, contingent, and reactive. Beijing's desire to shape and expand the reach of particular aspects of the international maritime legal order long predates its rise to great power status; in fact, when it comes to the Law of the Sea, China was a more enthusiastic rule-maker when it was a weak and insecure international player. Most interestingly, the PRC's internalization of the UNCLOS regime triggered a highly significant redefinition of its 'national interests' at sea - away from sovereignty over tiny disputed islands towards administrative control of vast international maritime spaces. Inspired by, and yet not compliant with, the emergent RBIO at sea, the PRC's subsequent pursuit of these new 'maritime rights and interests' using material power has not 
only become a major source of strategic mistrust, its defiance of UNCLOS processes has undermined the regime itself.

Second, the comparison reveals the influence of interactions between historical and geographical contingencies on the one hand, and the variables emphasized in IR theory, such as international structure, regime type, and ideational processes of interest construction. For some observers, the successful outcome from the first-ever UNCLOS-mandated compulsory conciliation case, that between Timor-Leste and Australia, provides a possible model for other countries, especially China (Koh, 2017). However, among the key factors facilitating Australia's eventual embrace of the RBIO at sea were two complex conditions constituted by interactions between contingency and structure: Australia's liberal domestic constitution combined with historical media events and earlier wartime ties between Australians and Timorese; and commercial interests combined with the Timor Sea's geographical peculiarities. These conditions underpinning Australia's switch to rule-observance in the Timor Sea dispute appear to absent in the case of the PRC in the South China Sea dispute.

Given how difficult shaping China's rise through processes of institutionalisation, socialisation and learning has proven to be, selective accentuation of existing rules may actually encourage the PRC to double down on the creation of its own parallel institutional orders (Beeson and Li 2016; Ikenberry and Lim 2017). Even more pertinently, the selective employment of principles on the part of Australia and the US is likely to encourage more rather than less strategic and geoeconomic assertion on the part of China. While the issue area of maritime sovereignty is still relatively novel, it is a manifestation of, and sheds light on, some of the most enduring features of contemporary international relations. 


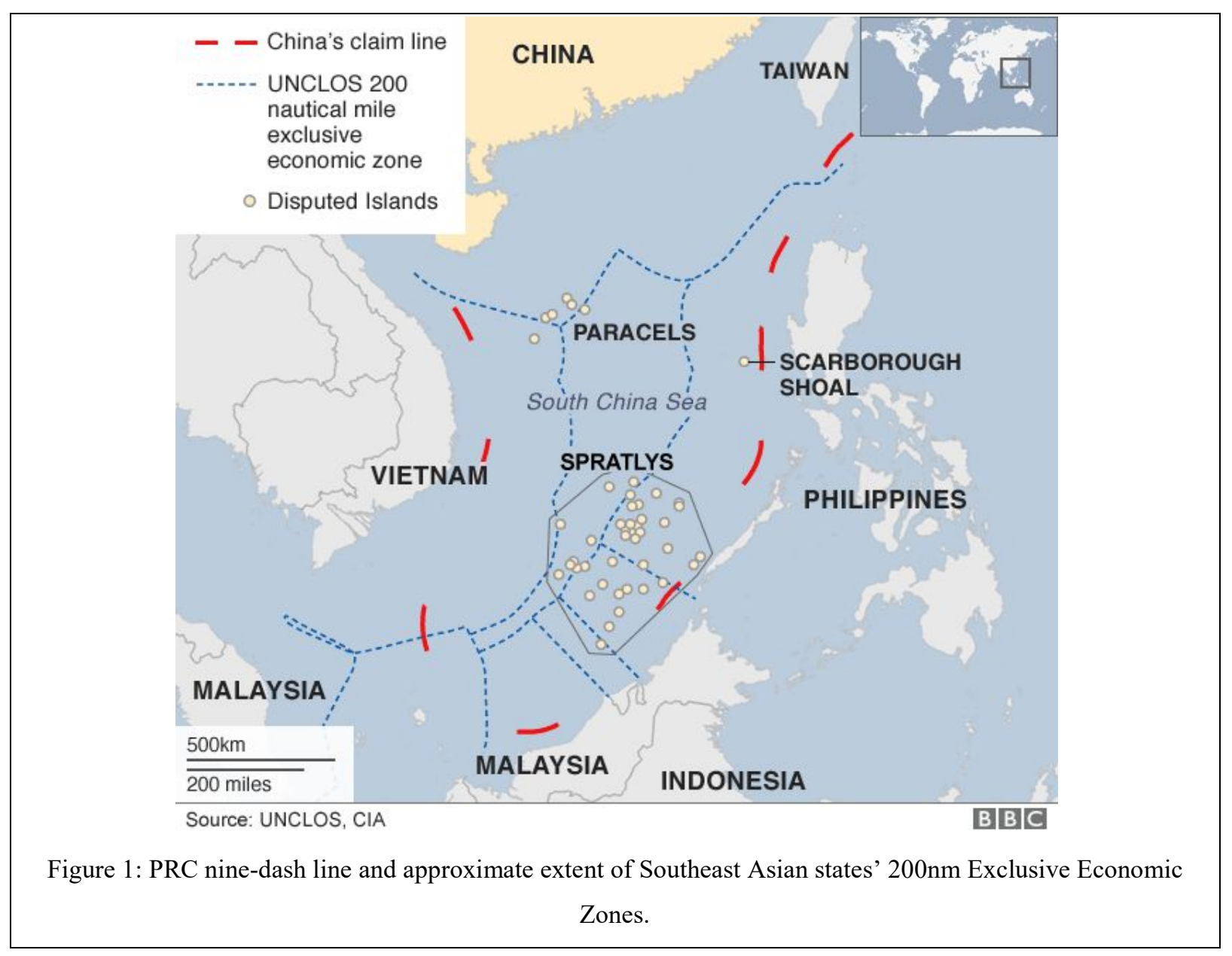




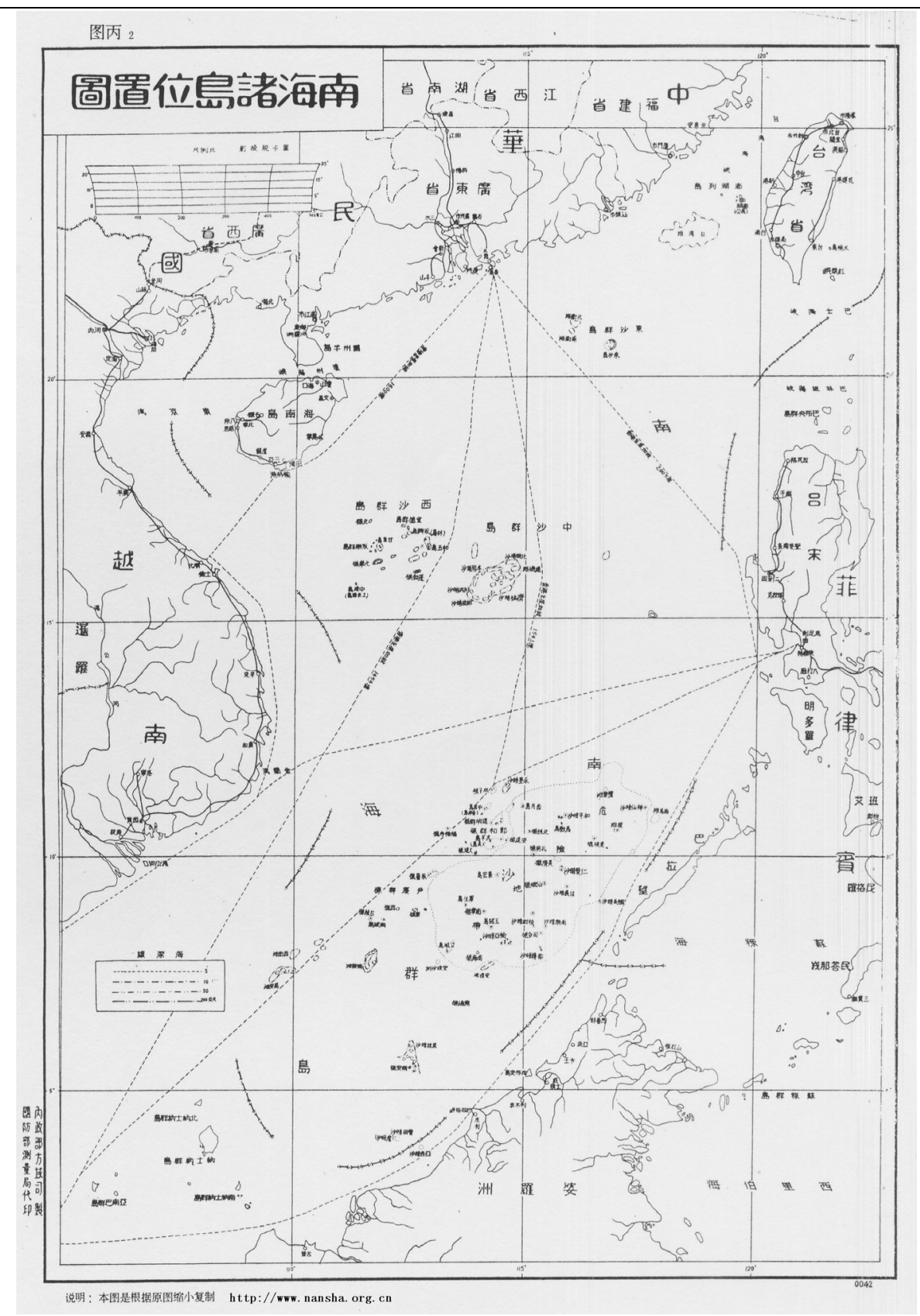

Figure 2: The original dashed-line map, titled Location Map of Islands in the South China Sea, as published by the Republic of China in 1948. 


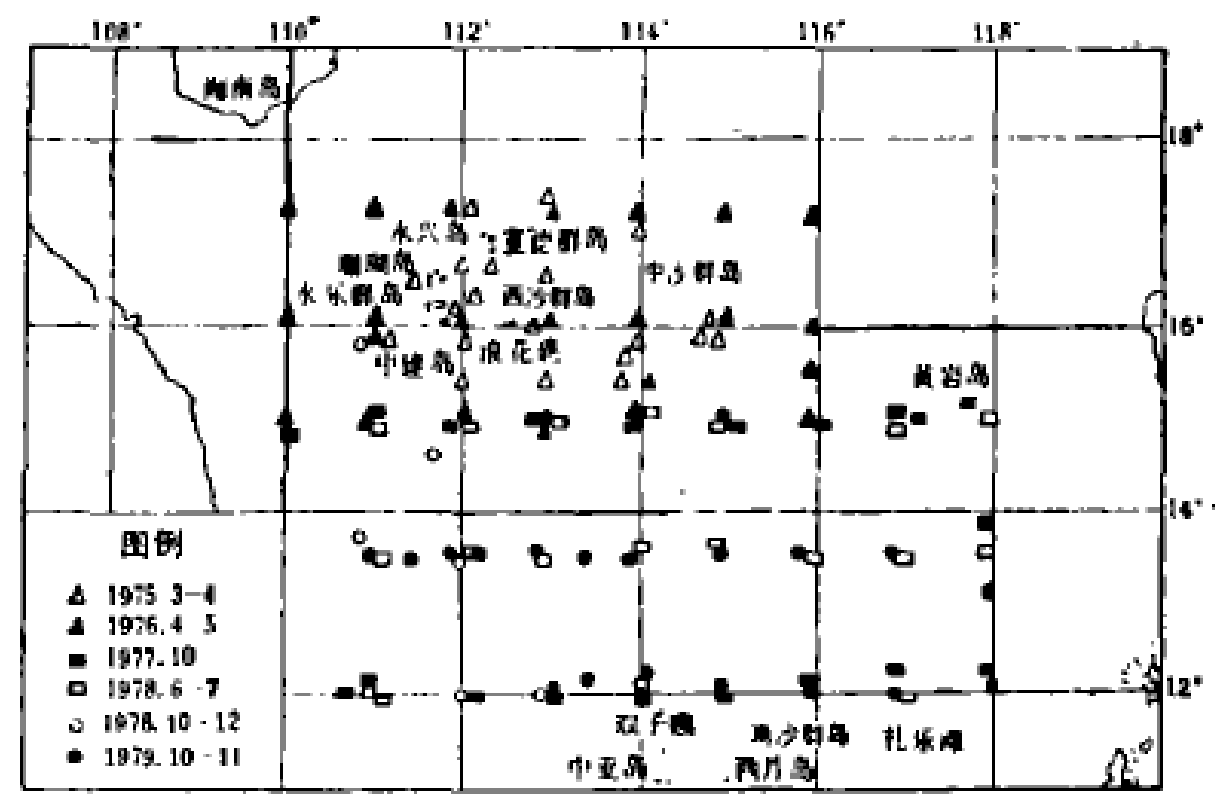

Figure 3: Expansion in the geographic scope of PRC Comprehensive Survey activities southward from the Paracel Islands, 1975-1979 (SOA, 1986)

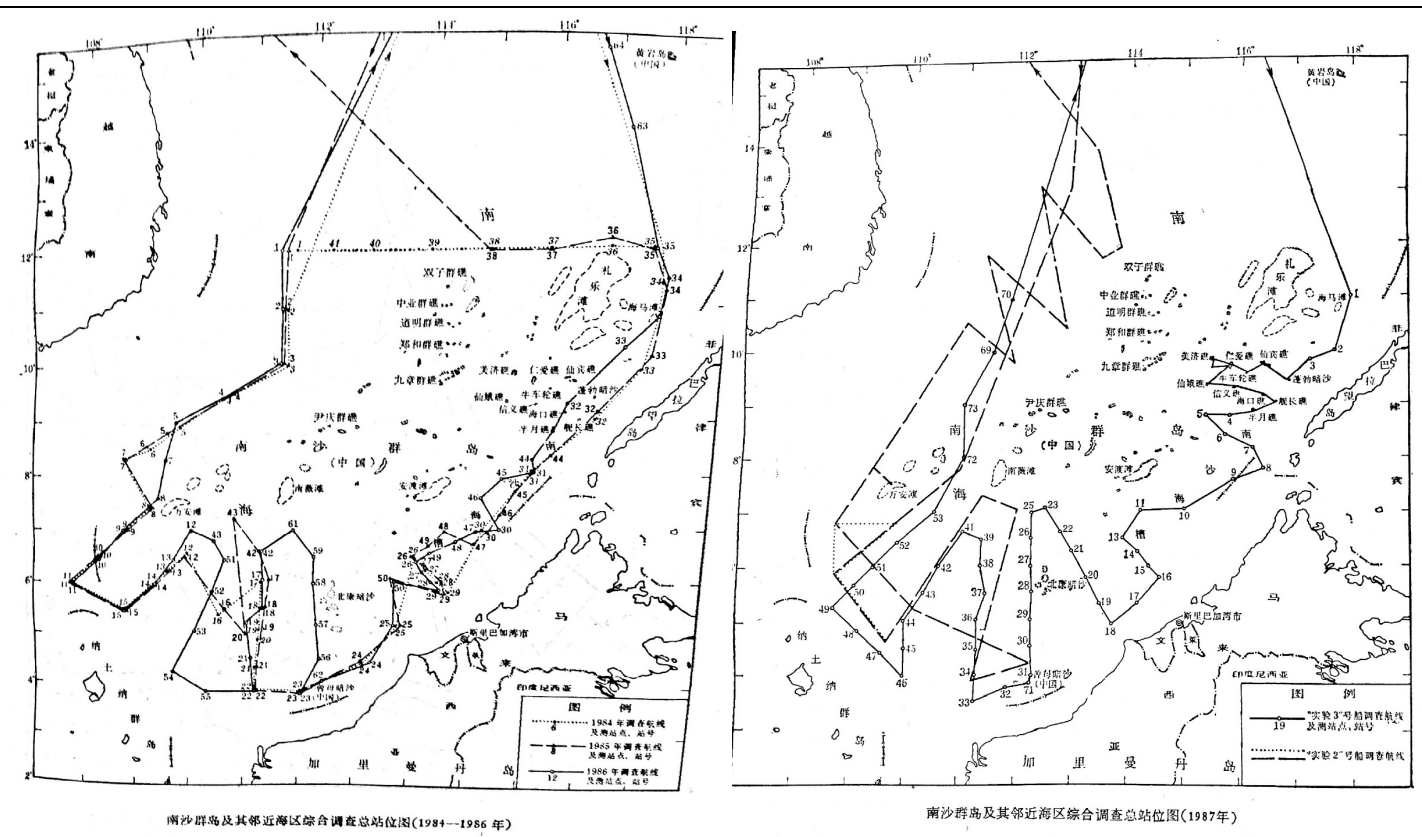

Figure 4: Route of 1984-1986 (L) and 1987 (R) Spratly Islands Comprehensive Surveys (CAS 1989). 


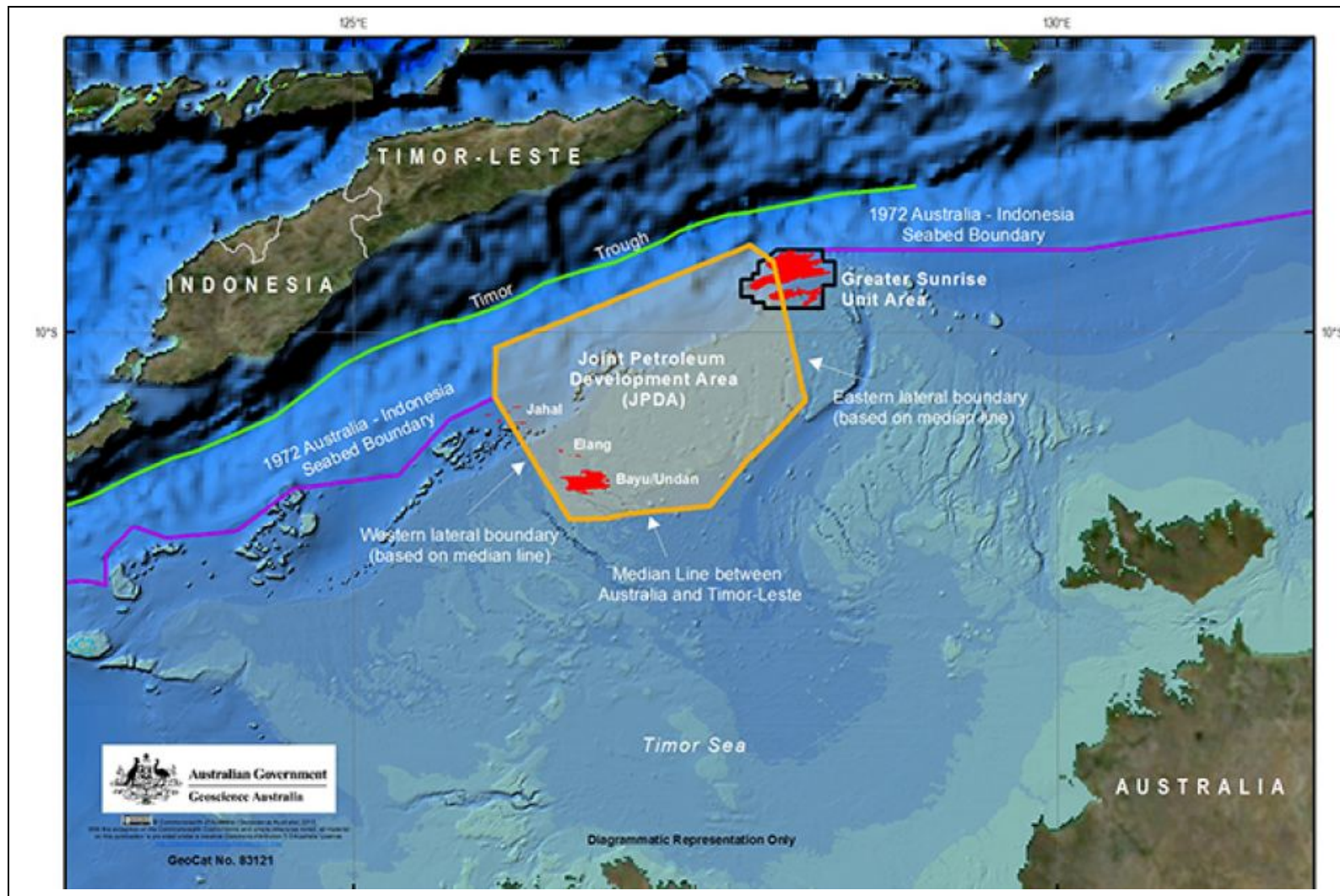

Figure 5: The 1972 Australia-Indonesia seabed boundary, and Timor Gap joint development area agreed by Indonesia and Australia in 1989.

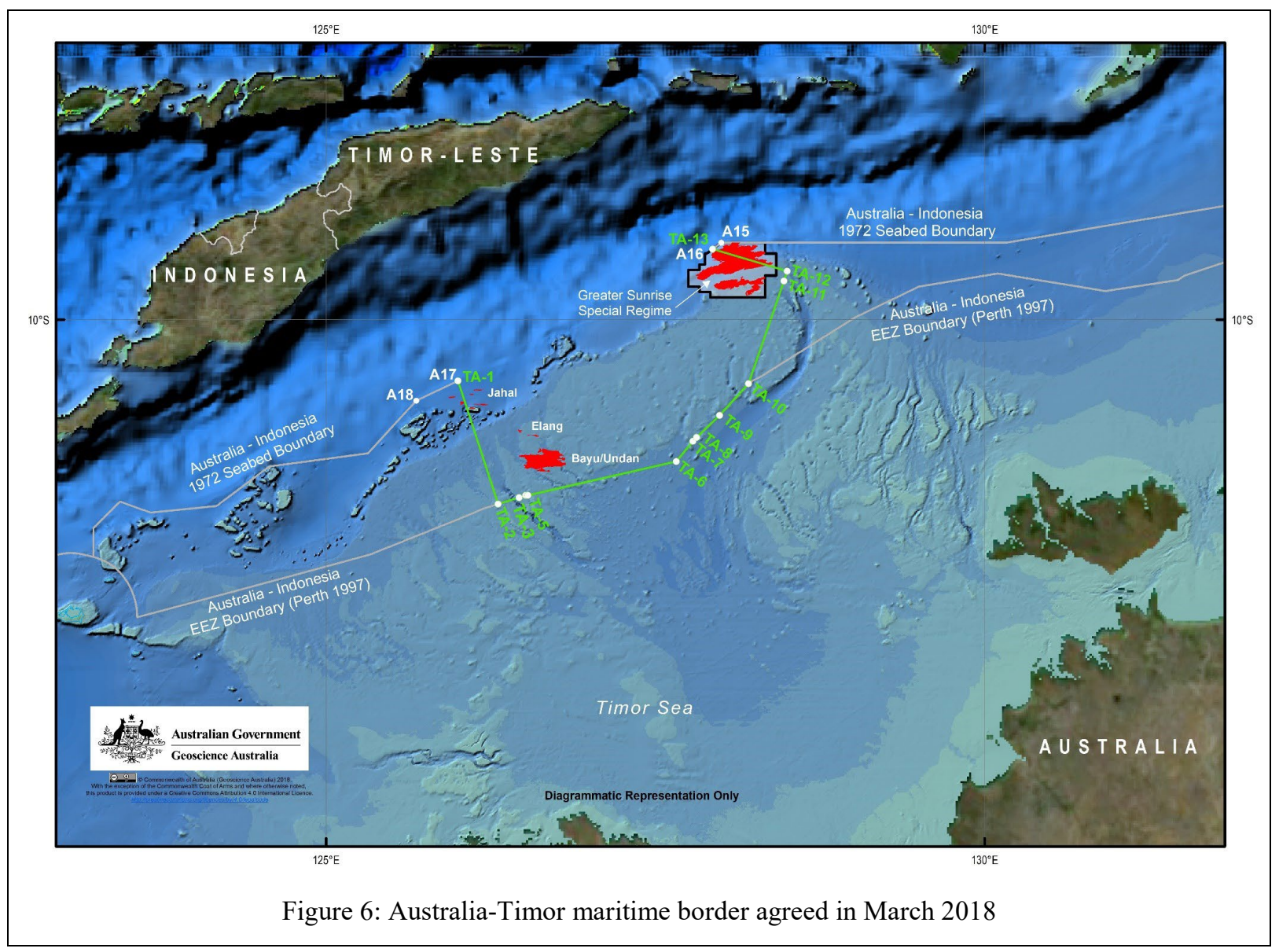




\section{References}

Agnew, J. (2018) Globalization and Sovereignty: Beyond the Territorial Trap, 2nd ed. (Latham: Rowman \& Littlefield Publishers).

Allard, T. (2016) 'East Timor takes Australia to UN over sea border' Sydney Morning Herald, 11 April.

Allison, G. (2018) 'The Myth of the Liberal Order', Foreign Affairs July/August.

ALP (2015) A Smart, Modern, Fair Australia: Labor National Platform, Barton, Australian Labor Party.

Beeson, M. (2014) Regionalism and Globalization in East Asia: Politics, Security and Economic Development, 2nd ed., Basingstoke, Palgrave.

Beeson, M. (2017) 'Alternative realities: Explaining security in the Asia-Pacific', Review of International Studies 43(3), 516-533.

Beeson, M. (2018) 'East Asia's institutional inadequacies and great power rivalry in the South China Sea', in, H. Feng and K. He (eds.), US-China Competition and the South China Sea Disputes. (London: Routledge):134150 .

Beeson, M. (2019) Rethinking Global Governance, (Basingstoke: Palgrave).

Beeson, M. and Li, F. (2016) 'China's place in regional and global governance: A new world comes into view', Global Policy 7(4): 491-499.

Bisley, N. (2018) 'Australia's rules-based international order'. Australian Outlook, July 27.

Bisley, N. and Schreer, B. (2018) 'Australia and the Rules-Based Order in Asia: Of Principles and Pragmatism', Asian Survey 58:2, 302-319.

Cannane, S. (2016) 'East Timor bugging scandal: Julie Bishop rejects former spy's bid to have passport returned'. $A B C$ News, 2 Feb.

Cannane, S., Koloff, S. and Andersen, B. (2015) "Matter of death and life': Espionage in East Timor and Australia's diplomatic bungle'. ABC News 26 November.

CAS (Chinese Academy of Sciences, 1989), Nansha Qundao Ji Qi Linjin Haiqu Zonghe Diaocha Yanjiu Baogao (Research Report on Comprehensive Survey of the Spratly Islands and Nearby Maritime Areas), Beijing, Kexue Chubanshe.

CAVR (2013), Chega! The Final Report of the Timor-Leste Commission for Reception, Truth and Reconciliation (Jakarta: KPG).

Chen, J. (1994) 'China's ASEAN policy in Deng Xiaoping's era: major political and security issues and general trends', PhD diss., Australian National University.

Chin, G. (2012) 'Two-way socialization', The Brown Journal of World Affairs 19(1): 211-230.

China Ocean News (2006) “Jinian woguo pizhun 'Lianheguo Haiyangfa Gongyue' shizhounian zuotanhui zai jing zhaokai (Forum marking 10th anniversary of our state's ratification of UNCLOS held in Beijing)," Zhongguo Haiyang Bao (China Ocean News) 1505, 17 May, at http://www.cso.org.cn/Xhdt/xuehuitongzhi/2013/0507/969.html

Clarke, T. (2018) 'Australia is guilty of same misconduct as China over our treatment of East Timor'. Sydney Morning Herald, 14 July. 
Cleary, P. (2007) Shakedown: Australia's Grab for Timor Oil, Crow’s Nest, Allen \& Unwin.

Chubb, A. (2019) 'Assessing public opinion's influence on foreign policy: the case of China's assertive maritime behavior’, Asian Security 15(2): 159-179.

Cotton, J. (2004) East Timor, Australia and Regional Order: Intervention and Its Aftermath in Southeast Asia, London, Routledge.

Dixon, D. (2017) 'Exploiting the Timor Sea: Oil, Gas, Water, and Blood ', University of New South Wales Law Research Series 46.

Evans, D. (2018a) 'Overblown expectations for East Timor's Greater Sunrise oil and gas'. Forbes March 2.

Gerring, J, and Seawright, J. (2007) Techniques for Choosing Cases. In Case Study Research. Cambridge: Cambridge University Press.

GoA (Government of Australia, 2016) 'Conciliation between Australia and Timor-Leste', Foreign Minister, August 29.

GoA (Government of Australia, 2017) 2017 Foreign Policy White Paper., Canberra, Commonwealth of Australia.

GoA (2018), ‘Australia's maritime arrangements with Timor-Leste', Department of Foreign Affairs and Trade, dfat.gov.au/geo/timor-leste/Pages/australias-maritime-arrangements-with-timor-leste.aspx

Haass, R.N. (2018) 'Liberal world order, R.I.P.'. Project Syndicate March 21.

Hodge, A. (2016) 'East Timor claims a win on boundary dispute with Australia', The Australian, August 27.

Ikenberry, G.J. (1998) 'Institutions, strategic restraint, and the persistence of the American postwar order', International Security 23(3), 43-78.

Ikenberry, G.J. and Lim, D.J. 2017. China's Emerging Institutional Statecraft: The Asian Infrastructure Investment Bank and the Prospects for Counter-hegemony. Washington: Brookings Institute.

Johnson, C.K. and Kennedy, S. (2015) 'China's Un-Separation of Powers', Foreign Affairs, July 24.

Johnston, A.I. (2008) Social States: China in International Relations, 1980-2000, Princeton, Princeton University Press.

Kagan, R. (2018) The Jungle Grows Back: American and Our Imperiled World, (New York: Knopf).

Kaplan, R.D. (2012) The Revenge of Geography: What the Map Tells US About the Coming Conflicts and the Battle Against Fate, (New York: Random House).

Katzenstein, P.J. and Sil, R. (2010) 'Analytic Eclecticism in the Study of World Politics: Reconfiguring Problems and Mechanisms across Research Traditions’ Perspectives on Politics 8(2), 411-434.

King, R.J. (2018) 'The Timor Gap, 1972-2018', submission to the Joint Standing Committee on Treaties on the Australia-Timor Leste Treaty Establishing Their Maritime Boundaries in the Timor Sea, April.

Krasner, S.D. (1982) 'Structural causes and regime consequences: regimes as intervening variables', International Organization 36(2): 185-205.

Lake, D.A. (2018) 'Economic Openness and Great Power Competition: Lessons for China and the United States', Chinese Journal of International Politics 11(3), 237-270.

Laksmana, E. (2017) 'Timor-Leste, Australia, and Asia's contested maritime order', Pell Center for International Relations and Policy. 
Lampton, D.M. (2015) 'Xi Jinping and the National Security Commission: policy coordination and political power', Journal of Contemporary China 24(95), 759-777.

Lardy, N.R. (2002) Integrating China into the Global Economy, Washington, Brookings Institution.

Macdonald-Smith, A. (2018) "Fresh start' needed on Sunrise LNG: Woodside CEO'. Australian Financial Review, July 22.

McGrath, K. (2017) Crossing the Line: Australia's Secret History in the Timor Sea, Carlton, Black Inc..

Martinson, R. (2018) Echelon Defense: The Role of Sea Power in China's Maritime Dispute Strategy, Newport, US Naval War College.

Mearsheimer, J.J. (1994/95) 'The false promise of institutions', International Security 19(3), 5-49.

Murdoch, L. (2018) 'Australia and East Timor strike 'landmark' deal to end Greater Sunrise dispute'. Sydney Morning Herald, 2 September.

Narizny, K. (2012) 'Anglo-American primacy and the global spread of democracy: An international genealogy', World Politics 64(02): 341-373.

Norington, B. and Stewart, C. (2019) 'US call for help battling China'. The Australian August 5.

Pedrozo, R. (2010) 'Coastal state jurisdiction over maritime data collection in the Exclusive Economic Zone: U.S. views,' in Peter Dutton ed., Military Activities in the EEZ, Newport, US Naval War College), 23-36.

Pereira-Coutinho, F. and Gala, F. (2005) 'David and Goliath revisited: A tale about Timor-Leste/Australia Sea agreements', Texas Journal of Oil, Gas and Energy Law 10(2), 429-462.

Rapp-Hooper, M. (2018) 'The liberal order is more than a myth', Foreign Affairs, 31 July.

Rothwell, D. (2018) '2018 Timor treaty', submission to Joint Standing Committee on Treaties with respect to the 2018 Treaty between Australia and the Democratic Republic of Timor-Leste, 20 April.

Schofield, C. and Strating, R. (2018) 'What's Next for Timor- Leste's Greater Sunrise?'. The Diplomat April 3.

Schofield, C. (2005) 'A "fair go" for East Timor? Sharing the resources of the Timor Sea', Contemporary Southeast Asia 27(2), 255-280.

Schofield, C. (2007) 'Minding the gap: The Australia-East Timor Treaty on Certain Maritime Arrangements in the Timor Sea (CMATS)' International Journal of Marine and Coastal Law 22, no. 2, 189-234.

Simpson, S. (2014) 'Google Earth Map for the Timor Sea Maritime Boundary Dispute', The View from LL2 (Blog), March 17, viewfromll2.com/2014/03/17/google-earth-map-for-the-timor-sea-maritimeboundary-dispute

Smyth, J. (2017) 'Australia ponders US military alliance in Trump era'. Financial Times, September 7.

Shan, X. (2012) 'Hai quan yue fa: Zhongguo canyu Lianheguo Haiyangfa Gongyue tanpan shimo (Maritime power and agreeing on the law: a full account of China's participation in the negotiation of the United Nations Convention on the Law of the Sea', Liaowang Dongfang Zhoukan (Oriental Outlook Weekly), December 10, at news.ifeng.com/shendu/lwdfzk/detail_2012_12/10/20017168_1.shtml

SOA (1986) Zhongguo Haiyang Nianjian 1986 (China Ocean Yearbook), Beijing, Haiyang Chubanshe.

SOA (1996) Zhongguo Haiyang 21 Shiji Yicheng (China's Maritime Agenda for the 21st Century) Beijing, State Oceanic Administration), at http://sdinfo.coi.gov.cn/hyfg/hyfgdb/fg8.htm

SOA (2000) Zhongguo Haiyang Nianjian 1999-2000 (China Ocean Yearbook), Beijing, Haiyang Chubanshe. 
SOA (2002) Zhongguo Haiyang Nianjian 2002 (China Ocean Yearbook), Beijing, Haiyang Chubanshe.

Staniland, P. (2018) 'Misreading the "liberal” international order' Lawfare, 29 July.

Steele, J. (2003) 'Anger in East Timor as Australia plays tough over gas reserves' The Guardian, 13 October.

Stokes, D. (2018) 'Trump, American hegemony and the future of the liberal international order', International Affairs 94(1), 133-150.

Strating, R. (2017) 'Timor-Leste's foreign policy approach to the Timor Sea disputes: pipeline or pipe dream?' Australian Journal of International Affairs 71(3), 259-283.

Strating, R. (2018) 'Maritime territorialization, UNCLOS, and the Timor Sea dispute', Contemporary Southeast Asia 40(1), 101-125.

Wang, Z. (2016) 'China and UNCLOS: an inconvenient history', The Diplomat, July 11.

Wolf, M. (2018) 'The new world disorder and the fracturing of the west'. Financial Times January 2.

Xi, J. 2018. Openness for Greater Prosperity, Innovation for a Better Future. Speech to the Boao Forum for Asia Annual Conference, April 10.

Xiao X. and Li S. (2013) 'Haishang weiquan douzheng yulunzhan duice sikao (Thoughts on public opinion warfare responses in the maritime rights struggle)', Guofang Keji (National Defense Science and Technology) 34(5): 99-103.

Xu Z. (2000), “'Zhongguo Haijian' - haiyang de 'tejingdui' ('China Marine Surveillance' - a 'special police unit' for the oceans)," Zhongguo Haiyang Bao (China Ocean News), no.914, May 9, at https://web.archive.org/web/20010309143435/http://www.soa.gov.cn/zfjc/914.htm

Zhang, L. (1996) Nansha Qundao Dashiji (Chronology of the Spratly Islands), Beijing, Zhongguo Kexueyuan.

Zhou, F. (2016) 'The U.S. Alliance System in Asia: A Chinese Perspective', Asian Politics \& Policy 8(1), 207218. 